\title{
THE IMPACT OF PERCEIVED ENVIRONMENTAL RESPONSIBILITY ON TOURISTS' INTENTION TO VISIT GREEN HOTEL: THE MEDIATING ROLE OF ATTITUDE
}

\author{
Ataul Karim PATWARY \\ Universiti Utara Malaysia, School of Tourism, Hospitality and Event Management, 06010 UUM, Sintok, Kedah, Malaysia, e-mail: raselataul@ gmail.com \\ Hamimi OMAR* \\ Universiti Utara Malaysia, School of Tourism, Hospitality and Event Management, 06010 UUM, Sintok, Kedah, Malaysia, e-mail: hamimi@uum.edu.my \\ Shaharuddin TAHIR \\ Universiti Utara Malaysia, School of Tourism, Hospitality and Event Management, 06010 UUM, Sintok, Kedah, Malaysia, e-mail: shah299@hotmail.com
}

\begin{abstract}
Citation: Patwary, A.K., Omar, H., \& Tahir, S. (2021). THE IMPACT OF PERCEIVED ENVIRONMENTAL RESPONSIBILITY ON TOURISTS' INTENTION TO VISIT GREEN HOTEL: THE MEDIATING ROLE OF ATTITUDE. GeoJournal of Tourism and Geosites, 34(1), 9-13. https://doi.org/10.30892/gtg.34101-612
\end{abstract}

\begin{abstract}
Although the hospitality and tourism industries contribute considerably to every country's economy, at the same time, it has negative effects on the climate. Hotel industry operations consume enormous amounts of energy which eventually contribute to environmental degradation. Hotel operations do not only cause environmental issues, but customers also play a significant role in creating these issues. Scholars, mainly in this field, have investigated the causes of environmental degradation from the perspective of hotel operations rather than customers. Therefore, this study aims to examine the influence of perceived environmental responsibility on tourists' attitude and intention to visit gre en hotels in Malaysia. It further examined the mediating role of attitude in between perceived environmental responsibility and intention. The study used a quantitative research design and interviewed 393 international tourists in Malaysia using systematic random sampling. For analysis techniques, the study used Structural Equation Modelling by PLS-SEM. The study found that consumers' perceived environmental responsibility influences significantly on tourists' attitude and intention. It also revealed that consumers' attitude mediates the in-between perceived environmental responsibility and intention to visit green hotels in Malaysia.
\end{abstract}

Key words: perceived environmental responsibility, attitude, intention, green hotels, tourism, Malaysia

$* * * * * *$

\section{INTRODUCTION}

Green practices in hotel refer to the adoption of the green system to operate the hotel operations that generally reduce the extra use of water and energy, more use of non-durable products, reduce unhealthy gas emission, water, oil and soil pollution (Lee et al., 2010). In recent years, several hotels have adopted the green practices for operating their business, as well as protecting the environment (Chandran and Bhattacharya, 2019; Wan et al., 2017; Rahman et al., 2012; Miao and Wei, 2016).

Many companies are motivated to invest in new environmental-friendly service and marketing strategies as the market's environmental consciousness is increasing rapidly (Chen and Chai, 2010). In the hotel industry, becoming green hotel is an underlying precondition to retain pro-environmental consumers who are more likely to buy and willing to pay for environmentally friendly lodging products (Chen and Tung, 2014; Han, 2015). Hotel industry ought to introduce environmentally sustainable accommodation by implementing green management techniques, eco-friendly standards and conservation practices to prevent adverse environmental effects (Han, 2015). If hotel managers pick and purchase a lodging-related commodity that represents the green needs of customers, they are responsible for implementing green strategies (Han and Kim, 2010). For instance, hoteliers should also consume a significant quantity of water, energy and disposable products that do not affect the environment (Han et al., 2010). While negative effects on the environment are evident in the hotel industry, the attitude of consumers towards green products remains unclear (Bohdanowicz et al., 2011). Environmentally friendly hotels aim to build green systemic changes that considerably decrease adverse environmental effects (Rahman and Reynolds, 2016; Lee et al., 2010).

It is achieved by the rigorous implementation of creative and successful Green practices such as solid waste reduction, energy and water conservation, and the recycling of all goods for the benefit of the environment (Greco et al., 2018; Han et al., 2010; Ham and Han, 2013). This study explores the effect on the attitude and intention of tourists to visit green hotels in Malaysia of their perceived environmental duty. It also explored the mediating role of attitude between environmental perceptions and intention to visit green hotels in Malaysia.

\section{LITERATURE REVIEW AND HYPOTHESIS DEVELOPMENT}

Intention

Behavioural intention refers to desire, ability or chance to do something (Ajzen, 1991), such as offering positive/negative advice, charging a premium, buying back or switching to another brand (Zeithaml et al., 1996). The behavioural intention identified by Warshaw and Davis (1985) is an intention of the person to perform a particular action or not. The goal of the present study is to explore consumers' intention to visit the green hotel. The previous research demonstrated that people are more likely to spend more money on the green hotel when they participate in a positive mouth-of-mouth activity (Han et al., 2009). Several studies (Chen and Peng, 2012; Lee et al., 2010) have found that customer attitudes towards positive green behaviour are a significant predictor of staying at a green hotel. The choice of customers to live in a green hotel is strongly affected by their perception of environmental effects and environmental responsibility (Han et al., 2010).

\section{Attitude}

Attitude has been the first component for measuring the intention of behaviour. Ajzen (1991) states that the attitude is "the degree to which a person has a favourable or unfavourable assessment or assessment of the behaviour" (p. 188). Attitude is the human tendency either

\footnotetext{
${ }^{*}$ Corresponding author
} 
positively or negatively towards something (Ajzen, 1991). Therefore, the green hotel sector is more likely to increase favourable attitudes towards green hotels (Han, 2015). Thus, through different media, constructive effects are produced that can lead to a positive attitude. Hoteliers should, for instance, support green campaigns that lead towards long-term green consumption (Han et al., 2010). The Green Campaign eventually raises consumers' environmental consciousness, which encourages customers to take more social responsibility and prefer green hotels in the future. Jauhari and Manaktola (2007) for example, stated that when tourism enterprises have implemented their green practices, they have increased the consumer's attitude towards the green hotel or their intention for a green hotel (Jauhari and Manaktola, 2007).

\section{Perceived Environmental Responsibility}

Sense of responsibility means that one's own life integrates meaning and expectations of self-categorization into a set of standards of identity (Stets and Burke, 2000). Because of an individual's reflection on social interactions, perceptions and systems of society and community, the environmental obligation is socially formed and expressed (Gill, 2012; Islam and Patwary, 2013). Over the years, consumers acquired knowledge and understanding of environmental problems (Lee, 2008). Some people may nevertheless take part in such activities or actions as a symbolic feature to establish a reputation or even to establish an appearance to others or to obtain an identity at the adolescent stage of life (Hormuth, 1999). Since pro-environmental behaviour is a special kind of altruistic act, in which a person establishes self-identity or introduces itself to others in society (Hopper and Nielsen, 1991; Lee, 2008). An individual is free from harm when he/she takes responsibility for the environment (Babcock, 2009). However, several environmental responsibility research in the seventies and eighties were performed (Follows and Jobber, 2000). They expressed concern that during that time, the assessment of the environmental effect of a product focussed primarily on behaviours of non-consumption such as energy conservation and political activism.

Based on the discussions above, this study proposed the hypotheses:

H1: "Attitude positively influences consumers' intention to visit green hotels in Malaysia."

H2: "Perceived Environmental Responsibility positively influences consumers' attitude towards green hotels in Malaysia."

H3: "Perceived Environmental Responsibility positively influences consumers' intention to visit green hotels in Malaysia."

H4: "Attitude mediates the relationship between attitudes and consumers' intention to visit green hotels in Malaysia."

\section{METHODOLOGY}

The research implemented a quantitative research method to analyze the effect of perceived environmental responsibility on tourists' attitude. Systemic random sampling was used in this research, as the survey was conducted in several tourist spots in Malaysia. International tourists in Malaysia were the target respondents of this research. The study sample is 393, and the entire response from Malaysia. A Likert scale of one to seven points (Strongly Disagree to Strongly Agree) has been used to measure questions. The research used data analysis software Smart-PLS version 3 and SPSS 24. For measuring perceived environmental responsibility, five items were adopted from Paço and Rodrigues, (2016); Manzo and Weinstein, (1987). For attitude, eleven items were adapted from Han et al. (2010) and Chen (2014). For measuring intention, four items adapted from Han et al. (2010) and Chen (2011).

\section{RESULTS}

\section{Demographic Information of the Respondents}

For demographic distribution of the respondents, they are sorted in terms of gender, age group, marital status, and occupation. Distribution of gender among respondents is almost the same as male $194(50.9 \%)$ and female 187 (49.1\%). In the age group, majority of the respondents are 28-32 years old (22.6\%), followed by 43-47 years (20.1\%), 33-37 years (18.8\%), 23-27 years (15.3\%), 38-42 years (8.4\%), 53 years and above $(4.8 \%)$ and $18-22$ years $(3.6 \%)$. In terms of marital status, $69 \%$ of the respondents are married, $106(27 \%)$ are single, 12 $(3.1 \%)$ are widows, and $4(1 \%)$ are divorced. For occupation, more than half of the respondents are working in government sector $(55.7 \%)$, followed by private sector (30.5\%), students $(5.9 \%)$, self-employed (5.6\%), housewife (1.8\%) and unemployed $(0.5 \%)$.

\section{Assessment of Measurement Model}

In the measurement model of the study, the outer loadings are good enough to fit into the construct (Table 1 and Figure 2). Outer loadings of the study for attitude are ranged from 0.727 to 0.854 . For intention, loadings are ranged from 0.816 to 0.900 . For perceived environmental responsibility, the outer loadings ranged from 0.744 to 0.913 .

Table 1. Construct Validity and Reliability

\begin{tabular}{|c|c|c|c|}
\hline Construct/ Associated Terms & Loading & Composite Reliability & Average Value Extracted \\
\hline Attitude & & \multirow{7}{*}{ 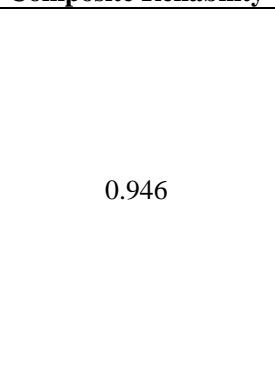 } & \multirow{7}{*}{ 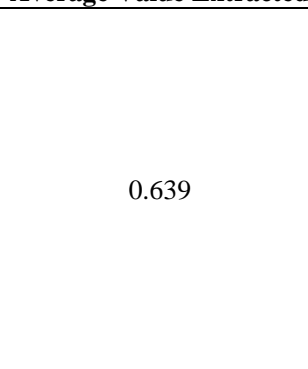 } \\
\hline ATT10 & 0.741 & & \\
\hline ATT3 & 0.773 & & \\
\hline ATT4 & 0.820 & & \\
\hline ATT5 & 0.832 & & \\
\hline ATT8 & 0.824 & & \\
\hline ATT9 & 0.727 & & \\
\hline \multicolumn{2}{|l|}{ Intention } & \multirow[b]{3}{*}{0.918} & \multirow[b]{3}{*}{0.738} \\
\hline INT1 & 0.878 & & \\
\hline INT2 & 0.900 & & \\
\hline PER2 & 0.908 & \multirow{4}{*}{0.937} & \multirow{4}{*}{0.750} \\
\hline PER3 & 0.901 & & \\
\hline PER4 & 0.913 & & \\
\hline PER5 & 0.744 & & \\
\hline
\end{tabular}


As shown in Table 1, Average Value Extracted for three variables shown in acceptable range as it is $0.639,0.738$ and 0.750 for attitude, intention, perceived environmental responsibility, respectively.

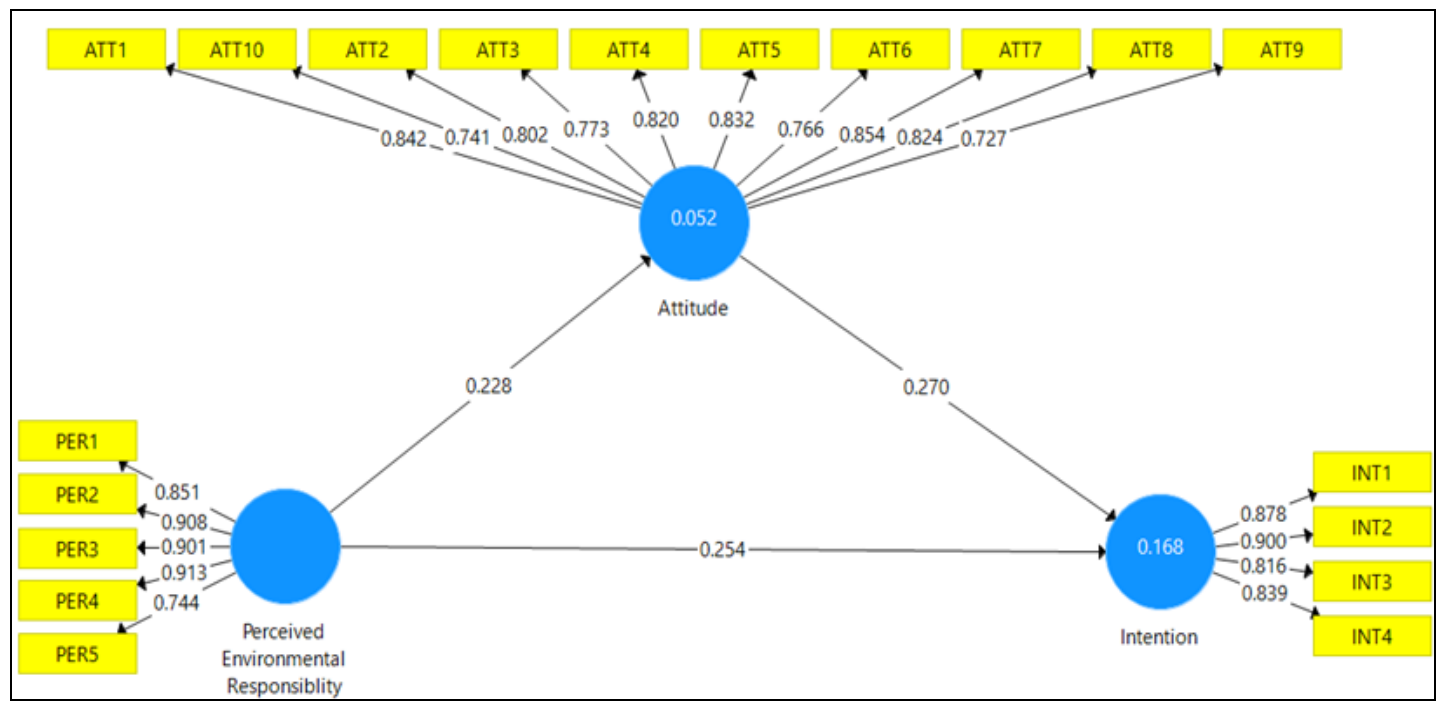

Figure 1. Measurement model of the study

The degree to which each latent variable is different from other models in the sample is discriminant validity (Hair et al., 2014; Patwary et al., 2020; Kamarudin et al., 2020). Two techniques, which are Heterotrait-Monotrait-Ratio (HTMT) and Fornell Larcker Criteria, were used to explain the discriminant validity.

Table 2. Discriminant validity Heterotrait-Monotrait Ratio (HTMT)

\begin{tabular}{|l|r|r|r|}
\hline & Attitude & Intention & Perceived Environmental Responsibility \\
\hline Attitude & & & \\
\hline Intention & $\mathbf{0 . 3 5 4}$ & & \\
\hline Perceived Environmental Responsibility & $\mathbf{0 . 2 3 7}$ & $\mathbf{0 . 3 3 7}$ & \\
\hline
\end{tabular}

Table.3. Discriminant validity Fornell-Larcker Criterion

\begin{tabular}{|l|c|c|c|}
\hline & Attitude & Intention & Perceived Environmental Responsibility \\
\hline Attitude & 0.799 & & \\
\hline Intention & 0.328 & 0.859 & \\
\hline Perceived Environmental Responsibility & 0.228 & 0.315 & 0.866 \\
\hline
\end{tabular}

Henseler et al., (2015) indicated that HTMT 0.85 and 0.9 standards for discriminatory validity should be identified. This research uses the more restrictive HTMT to test the legitimacy of discrimination. Tables 4 and 5 illustrate, in accordance with the Fornell Larcker criterion and the HTMT ratio, the results of the discriminating validity assessment and show that the model has justifiable discriminant validity.

In Table 4, Variance Inflation Factors is considered for testing the collinearity statistics. The highest collinearity counts for the overall model is 3.694, which is also acceptable. Other than that, all items in the study conceded very low collinearity which is good for model fitness.

Table 4. Collinearity Statistics (VIF)

\begin{tabular}{|c|c|}
\hline Outer VIF Values & VIF \\
\hline ATT1 & 3.618 \\
\hline ATT10 & 2.289 \\
\hline ATT2 & 2.973 \\
\hline ATT3 & 2.570 \\
\hline ATT4 & 2.861 \\
\hline ATT5 & 2.735 \\
\hline ATT6 & 2.416 \\
\hline ATT7 & 3.223 \\
\hline ATT8 & 2.770 \\
\hline ATT9 & 1.986 \\
\hline INT1 & 2.450 \\
\hline INT2 & 2.792 \\
\hline INT3 & 1.973 \\
\hline INT4 & 2.142 \\
\hline PER1 & 2.705 \\
\hline PER2 & 3.694 \\
\hline PER3 & 3.680 \\
\hline PER4 & 3.518 \\
\hline PER5 & 1.784 \\
\hline
\end{tabular}

\section{Assessment of Structural Model}

The diagram in figure 3 is shown to demonstrate the structural model of the study. T-values of the model are showing high efficiency in the construct. The influence of the independent variable to the dependent variable is positively significant. 
The bootstrapping method was performed in Smart PLS 3 to find the direct effects among the variables. The direct relationship of this study standardized into three, which are the influence of attitude on intention, the influence of perceived environmental responsibility on consumers' attitude, and the influence of perceived environmental responsibility on consumers' intention. The also posed an indirect relationship which is the mediating role of attitude in between attitudes and consumers' intention.

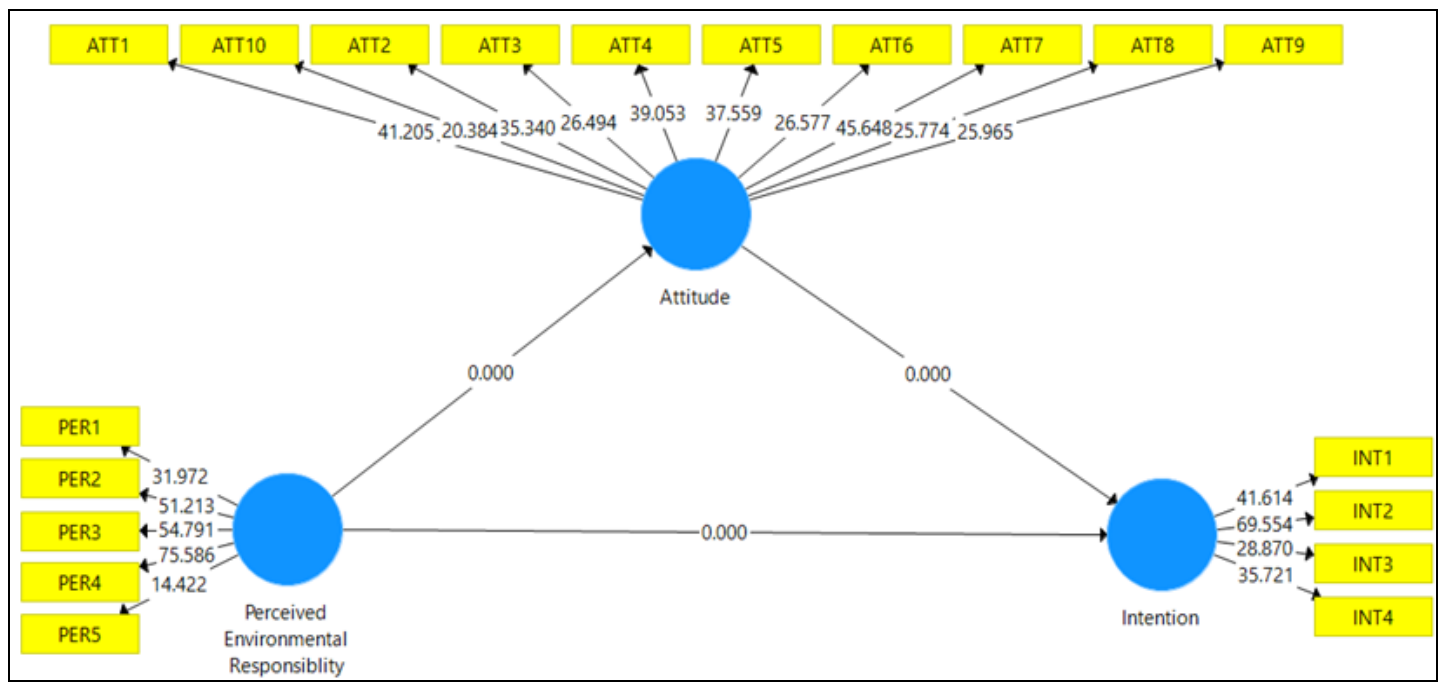

Figure 2. Structural Model of the Study

As shown in Table 5, attitude $(\mathrm{T}$ value $=5.311, \mathrm{p}$ value $=0.000)$, and perceived environmental responsibility $(\mathrm{T}$ value $=4.328, \mathrm{p}$ value $=$ 0.000) have significant relationship with intention. Besides, Perceived Environmental Responsibility also has significant relationship with attitude $(\mathrm{T}$ value $=4.253, \mathrm{p}$ value $=0.000)$

Table 5. The direct and indirect effects of the study

\begin{tabular}{|c|c|c|c|c|c|}
\hline Hypothesis & Relationship & Path Coefficient & $\mathrm{t}$ Value & $\mathrm{P}$ values & Supported \\
\hline $\mathrm{H} 3$ & Perceived Environmental Responsibility -> Intention & 0.254 & 4.328 & 0.000 & $\sqrt{ }$ \\
\hline
\end{tabular}

Table 5 also shows the results of the mediating effects of the study as this study considers attitude as a mediating variable between perceived environmental responsibility and intention. As shown in table 5, attitude plays a significant mediating role between perceived environmental responsibility and intention $(\mathrm{T}$ value $=3.165$, $\mathrm{p}$ value $=0.002)$.

\section{DISCUSSION}

The results of this study show that the relationship between consumer environmental perception and visiting green hotels is statistically significant. This indicates that the attitude in visiting green hotels in Malaysia has more impact on the environment. There are several studies supporting hypothesis findings (Lee, 2012; Johri and Sahasakmontri, 1998; Alom et al., 2019; Hassan et al., 2020).

The result also shows that consumers mediate the link between perceived environmental responsibility and tourists' behavioural intent in considering green practices in the Malaysian hotel industry. According to the theory, Kim (2011) pointed out that consumers with a high degree of environmental awareness should result in a positive disposition towards the environment, which would also be focused on buying goods which are deemed environmentally friendly. TPB and an extension TRA assert that the purchase intention of a person depends on his actions, and several others (Ajzen and Fishbein, 1980; Fishbein and Ajzen 1975). The hypothesis results show that attitude influences the behaviour of tourists concerning green practices in the Malaysian hotel industry in a significant way.

This finding is supported by Polonsky et al. (2012). According to TPB tenets, behavioural motives are known as the immediate precursor of behaviours (Ajzen and Fishbein, 1980), while convictions act as an immediate precursor (Ajzen, 1991).

\section{CONCLUSION}

An environmentally sustainable perception could lead to a positive attitude towards visits to green hotels. It was statistically achieved that the efforts of marketers towards adhering to offering useful information and environmental consciousness lead to formation of a favorable attitude among the consumers which further motivates them to consider these aspects by exerting a positive significant influence on their behavioral intention by taking into consideration the environmental aspects. It implies that managers must be putting in all efforts towards maintaining environmental protection across their marketing activities in order to ensure that consumers find their green products appropriate and fit starting from their initial assessment of products at the attitude formation stage to the intention development stage when consumers are planning to buy, and during the stage when consumers actually act upon.

\section{REFERENCES}

Ajzen, I. (1991). The theory of planned behaviour. Organizational Behaviour and Human Decision Processes, 50(2), 179-211. https://doi.org/10.1016/07495978(91)90020-T

Ajzen, I., Fishbein, M., \& Heilbroner, R.L. (1980). Understanding attitudes and predicting social behavior. Englewood Cliffs, NJ, Prentice hall, 278. https://doi.org/10.1108/03555554322009

Alom, S., Patwary, A.K., \& Khan, M.M.H. (2019). Factors Affecting the Turnover Intention of Bangladeshi Migrants in the United Arab Emirates: An Empirical Study on the Hotel Industry. International Journal of Innovation, Creativity and Change, 8(3), 344-360. https://doi.org/10.1111/ijcs.12272 
Babcock, H.M. (2009). Assuming personal responsibility for improving the environment: Moving toward a new environmental norm. Harv. Envtl. L. Rev, 33, 117-175. https://doi.org/10.1080/10976645.2012.695291

Biswas, C., Omar, H., \& Rashid-Radha, J.Z.R.R. (2020). The Impact of Tourist Attractions and Accessibility on Tourists' Satisfaction: The Moderating Role of Tourists' Age. Geojournal of Tourism and Geosites 32(4), 1202-1208. https://doi.org/10.30892/gtg.32402-558

Bohdanowicz, P., Zientara, P., \& Novotna, E. (2011). International hotel chains and environmental protection: an analysis of Hilton's we care! programme (Europe, 2006-2008). Journal of Sustainable Tourism, 19(7), 797-816. https://doi.org/10.1080/09669582.2010.549566

Chandran, C., \& Bhattacharya, P. (2019). Hotel's best practices as a strategic driver for environmental sustainability and green marketing. Journal of Global Scholars of Marketing Science, 29(2), 218-233. https://doi.org/10.1080/21639159.2019.1577156

Chen, A.H., \& Peng, N. (2012). Green hotel knowledge and tourists' staying behavior. Annals of Tourism Research. 39(4), 2211-2216. https://doi.org/10.1016/j.annals.2012.07.003

Chen, M.F., \& Tung, P.J. (2014). Developing an extended theory of planned behaviour model to predict consumers' intention to visit green hotels. International journal of hospitality management, 36, 221-230. https://doi.org/10.1016/j.ijhm.2013.09.006

Chen, T. B., \& Chai, L.T. (2010). Attitude Towards the Environment and Green Products: Consumers' Perspective. Management Science and Engineering, 4(2), 27-39. https://doi.org/10.3968/j.mse.1913035X20100402.002

Fishbein, M., \& Ajzen, I. (1975). Belief, Attitude, Intention, and Behavior: An Introduction to Theory and Research. Reading. MA, Addison-Wesley. https://doi.org/10.1108/EBR-10-2013-0128

Follows, S.B., \& Jobber, D. (2000). Environmentally responsible purchase behaviour: a test of a consumer model. European journal of Marketing, 34(5/6), 723-746. https://doi.org/10.1108/03090560010322009

Gill, F. (2012). Practicing environmental responsibility: local and global dimensions. Social Responsibility Journal, 8(1), 21-32. https://doi.org/10.1108/17471111211196548

Greco, G., Cenciarelli, V.G., \& Allegrini, M. (2018). Tourism's impacts on the costs of municipal solid waste collection: Evidence from Italy. Journal of cleaner production, 177, 62-68. https://doi.org/10.1016/j.jclepro.2017.12.179

Hair Jr.J., Sarstedt, M., Hopkins, L., \& G. Kuppelwieser, V. (2014). Partial least squares structural equation modeling (PLS-SEM) An emerging tool in business research. European Business Review, 26(2), 106-121. https://doi.org/10.1108/EBR-10-2013-0128

Ham, S., \& Han, H. (2013). Role of perceived fit with hotels' green practices in the formation of customer loyalty: Impact of environmental concerns. Asia Pacific Journal of Tourism Research, 18(7), 731-748. https://doi.org/10.1080/10941665.2012.695291

Han, H. (2015). Travelers' pro-environmental behaviour in a green lodging context: Converging value-belief-norm theory and the theory of planned behaviour. Tourism Management, 47 (1), 164-177. https://doi.org/10.1016/j.tourman.2014.09.014

Han, H., \& Kim, Y. (2010). An investigation of green hotel customers' decision formation: Developing an extended model of the theory of planned behaviour. International Journal of Hospitality Management, 29(4), 659-668. https://doi.org/10.1016/j.ijhm.2010.01.001

Han, H., Hsu, L.T.J., \& Sheu, C. (2010). Application of the theory of planned behaviour to green hotel choice: Testing the effect of environmental friendly activities. Tourism management, 31(3), 325-334. https://doi.org/10.1016/j.tourman.2009.03.013

Han, H., Hsu, L.T., \& Lee, J.S. (2009). Empirical Investigation of the roles of Attitudes Towards Green Behaviours, Overall Image, Gender, and Age in Hote Customers' Ecofriendly Decision-making Process. International Journal of Hospitality Management, 28(4), 519-528. https://doi.org/10.1016/j.ijhm.2009.02.004

Hasan, A.T, Biswas, C., Roy, M., Akter, S., \& Kuri, B.C. (2020). The Applicability of Theory of Planned Behaviour to Predict Domestic Tourist Behavioural Intention: The Case of Bangladesh. GeoJournal of Tourism and Geosites, 31(3), 1019-1026. https://doi.org/10.30892/gtg.31313-536

Henseler, J., Ringle, C.M., \& Sarstedt, M. (2015). A new criterion for assessing discriminant validity in variance-based structural equation modeling. Journal of the academy of marketing science, 43(1), 115-135. https://doi.org/10.1007/s11747-014-0403-8

Hopper, J.R., \& Nielsen, J.M. (1991). Recycling as altruistic behaviour: Normative and behavioural strategies to expand participation in a community recycling program. Environment and behaviour, 23(2), 195-220. https://doi.org/10.1177\%2F0013916591232004

Hormuth, S.E. (1999). Social meaning and social context of environmentally-relevant behaviour: shopping, wrapping, and disposing. Journal of environmental psychology, 19(3), 277-286. https://doi.org/10.1006/jevp.1999.0134

Islam, R., \& Patwary, A.K. (2013). Factors influencing to the policy and strategies used to disabled employment in hospitality industry. Advances in Environmental Biology, 2598-2606. https://doi.org/10.1108/02683941211220153

Jauhari, V., \& Manaktola, K. (2007). Exploring consumer attitude and behaviour towards green practices in the lodging industry in India. International journal of contemporary hospitality management, 19(5), 364-377. https://doi.org/10.1108/09596110710757534

Johri, L.M., \& Sahasakmontri, K. (1998). Green marketing of cosmetics and toiletries in Thailand. Journal of consumer marketing, 15(3), 265-281. https://doi.org/10.1108/07363769810219134

Kamarudin, L.M., Patwary, A.K., \& Mahmud, S.R.A. (2020). Measuring Perceived Benefits and Financial Performance in Mice Tourism: The Mediating Role of Web 2.0 Adoption Intention. Hamdard Islamicus, 43(2), 972-992. https://doi.org/11.24244/isda.v8i1.6344

Lee, J.S., Hsu, L.T., Han, H., \& Kim, Y. (2010). Understanding how consumers view green hotels: how a hotel's green image can influence behavioural intentions. Journal of sustainable tourism, 18(7), 901-914. https://doi.org/10.1080/09669581003777747

Lee, K. (2014). Predictors of sustainable consumption among young educated consumers in Hong Kong. Journal of International Consumer Marketing, 26(3), 217-238. https://doi.org/10.1080/08961530.2014.900249

Manzo, L.C., \& Weinstein, N.D. (1987). Behavioural commitment to environmental protection: A study of active and nonactive members of the Sierra Club. Environment and Behaviour, 19(6), 673-694. https://doi.org/10.1177\%2F0013916587196002

Miao, L., \& Wei, W. (2016). Consumers' pro-environmental behaviour and its determinants in the lodging segment. Journal of Hospitality \& Tourism Research, 40(3), 319-338. https://doi.org/10.1177\%2F1096348013495699

Paço, A., \& Gouveia Rodrigues, R. (2016). Environmental activism and consumers' perceived responsibility. International Journal of Consumer Studies, 40(4), 466-474. https://doi.org/10.1111/ijcs.12272

Patwary, A. K., Omar, H., \& Tahir, S. (2020). A Conceptual Model of What Influences Consumers When Visiting Green Hotels in Malaysia. International Journal of Innovation, Creativity and Change, 11(11), 11-25. https://doi.org/10.22164/isea.v8i1.88

Polonsky, M.J., Vocino, A., Grau, S.L., Garma, R., \& Ferdous, A.S. (2012). The impact of general and carbon-related environmental knowledge on attitudes and behaviour of US consumers. Journal of Marketing Management, 28(3-4), 238-263. https://doi.org/10.1080/0267257X.2012.659279

Rahman, I., \& Reynolds, D. (2016). Predicting green hotel behavioural intentions using a theory of environmental commitment and sacrifice for the environment. International Journal of Hospitality Management, 52, 107-116. https://doi.org/10.1016/j.ijhm.2015.09.007

Rahman, I., Reynolds, D., \& Svaren, S. (2012). How "green" are North American hotels? An exploration of low-cost adoption practices. International Journal of Hospitality Management, 31(3), 720-727. https://doi.org/10.1016/j.ijhm.2011.09.008

Stets, J.E., \& Burke, P.J. (2000). Identity theory and social identity theory. Social psychology quarterly, 63(3) 224-237. https://doi.org/10.2307/2695870

Wan, Y.K.P., Chan, S.H.J., \& Huang, H.L.W. (2017). Environmental awareness, initiatives and performance in the hotel industry of Macau. Tourism Review, 72(1), 87-103. https://doi.org/10.1108/TR-06-2016-0016

Warshaw, P.R., \& Davis, F.D. (1985). Disentangling behavioural intention and behavioural expectation. Journal of experimental social psychology, 21(3), 213-228. https://doi.org/10.1016/0022-1031(85)90017-4

Zeithaml, V.A., Berry, L.L., \& Parasuraman, A. (1996). The behavioural consequences of service quality. Journal of marketing, 60(2), 31-46. https://doi.org/10.2307/1251929 